Journal Universitas Muhammadiyah Gresik Engineering, Social Science, and Health International Conference (UMGESHIC)

UMGCINMATIC : $1^{\text {st }}$ Rethinking Education during Covid-19 Era: Challange and Innovation

\title{
EFFECT OF APPLING FLIPPED CLASSROOM ON ENGLISH ACHIEVEMENT OF PRIMARY 5 STUDENTS IN COVID-19 SITUATION
}

\author{
Author \\ Yupha Phumphanit ${ }^{1}$, Anisatur Rohmawati ${ }^{2}$, Wanida Simpol ${ }^{3}$ \\ ${ }^{1}$ Ban Nonkokkha School, Phakhao, Loei 42240, Thailand \\ ${ }^{2}$ Universitas Muhammadiyah Gresik, East Java 61121, Indonesia \\ ${ }^{3}$ Loei Primary Educational Service Area Office 2, Wangsaphung, Loei 42130, Thailand
}

\begin{abstract}
This research was collaboratively conducted with Indonesian students and aimed to 1) develop and evaluate the efficiency of Flipped Classroom management, 2) investigate the efficiency of Flipped Classroom management, and 3) examine learning achievement in English of Primary 5 students at Ban Nonkokkha school in Covid-19 situation. The target groups consisted of 32 students learning by using Flipped Classroom lesson plans in Covid-19 situation. The Flipped Classroom lesson plan for teaching in Covid - 19 situation in semester 1 of Academic year 2021 were used to collect the data from June to October 2021. The research tools were Flipped Classroom lesson plans consisted of 12 plans for 12 hours, pretest and posttest. The data was analysed using descriptive statistics for data analysis including frequency, percentage, mean, standard deviation, average efficiency value, index of efficiency, and relative gain scores.

The results of the research were as follows. 1) For the evaluation of the use of Flipped Classroom lesson plans for Primary 5 students, each of the lesson plans was averagely scored $3.67-4.33$. Overall, the lesson plans were averagely scored at high level $(\overline{\mathrm{x}}=4.25$, S.D. $=0.60)$, the efficiency (E1/E2) was 83.03/78.54 which was higher than the preset criteria. 2) The index of efficiency of Flipped Classroom lesson plans was 0.6741, and the students' improvement increased 67.41 percent. 3) The students' learning achievement analysed from the relative gain scores of learning achievement results showed that the percentage of pretest scores was 34.17 whereas the percentage of posttest score was 78.54 , and the percentage of growth score was 67.34 of which was interpreted as high level. When classifying based on the criteria, it was found that there were 7 students scored very high growth, 21 students' high growth, and 4 students scored moderate growth.
\end{abstract}

Keyword: English achievement, Flipped Classroom, Covid-19 


\section{UMGCINMATIC : $1^{\text {st }}$ Rethinking Education during Covid-19 Era: Challange and Innovation}

Volume 1 No 2

\section{INTRODUCTION}

English Language is essential and necessary in daily life since it is an international universal language for communicating and searching for knowledge, occupation, and higher educational level. In addition, it is used as a medium to enhance understanding of the culture and vision of the global community (Ministry of Education, 2008. The Basic Education Core Curriculum B.E.2521 (2008) focuses on developing learners to be able to achieve communication level of all four skills of English languages: listening, speaking, reading, and writing skills (Ministry of Education, 2008).

Due to the situation of Coronavirus Disease 2019 or COVID-19 situation, this resulted on the closure of educational institutions and affected learning processes of more than 1.5 billion students, or more than $90 \%$ of all students around the world. Consequently, the Ministry of Education suggested 5 formats of teaching management: 1) On Site: students can come to study normally, 2) On Air: teaching broadcasted via DLTV, 3) Online: teachers' teaching through the teaching and learning materials provided and distributed from schools to the students, the teaching approach widely performed by the largest number of teachers, 4) On Demand : teaching format through various applications, and 5) On Hand : providing worksheets for students (Amporn Pinasa, 2021).

Ban Nonkokkha School is a medium-sized school supporting students with English learning activities from Primary 1-6. According to the results of the learning activities in the foreign language learning subject group, it was found that English learning achievements of Primary 5 students based on the average point in the academic year 2020 was found unsatisfied since students lacked of learning process skill and knowledge inquiring skill. Moreover, teachers did not have appropriate techniques and teaching approaches that stimulated students to be interested in learning, and students did not have opportunity to practice using language authentically in daily life. Therefore, the researcher tried to study the educational theories for solving the problems to develop learning activities for English courses, and it was found that Flipped classroom learning management is a teaching style consistent with the current teaching and learning situation as it was defined as "Studying at home, doing homework at school". Flipped classroom is a type of classroom management in which the activity changes from teachers describing content in classrooms into creating or introducing learning materials, having students go back to study at home, and turning the classroom activities into activities based on the lessons that students have already studied to practice problem-solving skill and create interactions in the classroom, and including apply the obtained knowledge. It is a learning management innovation that is consistent with the development of learners' skills in the 21st century (Supattra Utamang, 2015). Additionally, flipped classroom can be conducted by assigning students to prepare for the next lesson by watching videos or other media before studying in the class focusing on the participation of learners. Teachers can create their teaching in forms of videos based on academic content for learners to learn before regularly attending classes as well as design courses to enhance valuable learning time where students have more involvement in classroom activities. This will additionally facilitate students' learning provided by teachers (Milman, 2012). This concept of teaching has been implemented by many educational institutions and groups of learning subjects for teaching and learning management. 
According to the reasons and importance mentioned above, the researcher recognized the importance of developing English proficiency skills to enhance Primary 5 students' learning achievement by implementing the Flipped-classroom through On Demand and Online learning management via various applications together with students from Indonesia to be a guideline to develop teaching English better.

\section{METHOD}

\section{A. Participants}

The target group of this research consisted of 32 students of Primary 5, Ban Nonkokkha School, Pha Khao District, Loei Province, Loei Primary Educational Service Area Office 2, who were studying in the semester 1 of the academic year 2021, using a purposive sampling method for selecting the samples.

\section{B. Measures}

The research tools were:

1. Flipped Classroom lesson plans for Primary 5 students: 12 lesson plans, 12 hours, divided into 3 learning units as follows (Semester 1/2014).
1. Unit: Our favourite dishes:
4 Lesson plans 4 hours
2. Unit: It's more interesting:
4 Lesson plans 4 hours
3. Unit: Safety first:
4 Lesson plans 4 hours

2. Multiple choice test to investigate the students' English learning achieving before and after learning by using the designed lesson plans, contained 30 items, 30 points ( 1 point each)

\section{Procedure and design}

Procedure and design were one group pretest and posttest design. Learning units 1-3 were used to create a learning activity plans for data collection. The lesson plans were constructed through 6 stages as follows.

\section{Before teaching}

Stage 1: Plan. Teachers designed lesson plans by identifying teaching objectives, selecting teaching media and supplementary activities which are appropriate for the learner's ages, classrooms, and the school contexts.

Stage 2: Warm-up. Teachers record and prepare video for teaching. Teachers may record their own teaching or using other videos in which the content contained all learning indicators.

Stage 3: Share. Teachers share teaching videos to students and explain about the content of the video to be taught the classroom (at this stage, the teachers may create an activity or give out a preclass quiz for students to try before teaching in the classroom).

\section{In classroom}

Stage 4: Knowledge Sharing. This stage is an exchanging of knowledge to promote interaction in classroom. Teachers extend the students opportunity to discuss, exchange and ask questions based on the content they have already studied from the video in order to develop analytical thinking and communicating skill. 
Stage 5: Group work. Students are divided into groups to achieve the results as planned. Dividing students into groups, students can work together on the topic assigned by the teachers or help each other choose a topic to work on to develop creative and collaborative skills (in the meantime, teachers can observe to assess students during presentations. Teachers may assign to do exercises or worksheets.)

Stage 6: Discussion. Students return in group again for group work presentation. It is a platform provided for all classmates to share opinions and ask questions.

\section{After teaching}

Review teaching to find out whether the designed lesson plans, videos, and materials included in the plans are effective or not, how effective the lesson plans are, and how are the results of the assessment and the evaluation of teachers' teaching as well.

Review the lesson plans after using for teaching, including teaching media and learning activities to find out how much the students understand the lessons.

Revise the lesson plans in case there are number of students remain questioned about the content. Teachers need to revise the lesson plans in order to enhance the students' better understanding.

Repeat if the teaching outcome is effective. Teachers repeat using the effective lesson plans and provide students with challenging activities so that students can use their advance level skills.

\section{Data analysis}

1. Part 1 : The evaluation results of using flipped classroom management lesson plans for Primary 5 students.

2. Part 2: The results of the review of the effectiveness of Flipped Classroom Management lesson plans for Primary 5 students.

3. Part 3: The results of the study of academic achievement of Primary 5 students 'learning by implementing flipped classroom lesson plans in the situation of COVID-19 situation.

According to the study of the problem conditions and the database to develop English language proficiency skills to enhance learning achievement together with the flipped classroom concept of Primary 5 students, the researcher found that for English learning management context of Ban Nonkokkha School, students still have problems in listening, speaking, reading, and writing needed to be improved or improved to reach the higher level. The researcher studied how to apply the concept of Flipped Classroom to improve English language achievement for students to successfully achieve learning objectives. Finally, the researcher designed the lesson plans consisted of 12 plans for 12 hours, divided into 3 learning units as follows (Semester 1/2019).
1. Unit: Our favourite dishes
4 plans and 4 hours.
2. Unit: It's more interesting
4 plans and 4 hours.
3. Unit: Safety first
4 plans and 4 hours. 


\section{RESULTS}

\section{A. Data analysis results}

Part 1 the results of the Flipped Classroom Management Plans for Primary 5 students evaluated by 3 experts.

Table 1. Assessment results of the Flipped Classroom Learning Management Plan for Primary 5 students by 3 experts.

\begin{tabular}{|c|c|c|l|}
\hline Lesson plan & $\begin{array}{c}\text { Mean } \\
(\overline{\mathrm{x}})\end{array}$ & $\begin{array}{c}\text { Standard } \\
\text { Deviation }(\text { S.D) }\end{array}$ & \multicolumn{1}{|c|}{ Meaning } \\
\hline 1 & 4.67 & 0.58 & Highest quality and appropriateness \\
\hline 2 & 4.33 & 0.58 & High quality and appropriateness \\
\hline 3 & 4.33 & 0.58 & High quality and appropriateness \\
\hline 4 & 4.33 & 0.58 & High quality and appropriateness \\
\hline 5 & 4.33 & 0.58 & High quality and appropriateness \\
\hline 6 & 4.33 & 0.58 & High quality and appropriateness \\
\hline 7 & 4.33 & 0.58 & High quality and appropriateness \\
\hline 8 & 4.00 & 1.00 & High quality and appropriateness \\
\hline 9 & 4.00 & 1.00 & High quality and appropriateness \\
\hline 10 & 4.67 & 0.58 & High quality and appropriateness \\
\hline 11 & 3.67 & 0.58 & High quality and appropriateness \\
\hline 12 & 4.00 & 0.00 & High quality and appropriateness \\
\hline Overall & $\mathbf{4 . 2 5}$ & $\mathbf{0 . 6 0}$ & High quality and appropriateness \\
\hline
\end{tabular}

According to Table 1, the results of using Flipped Classroom lesson plans for Primary 5 students evaluated by experts were averagely scored from $3.67-4.33$, the overall mean score was 4.25 , and standard deviation was 0.60 . For the efficiency of the Flipped Classroom lesson plans for Primary 5 students, it was found that the quality and appropriateness of each lesson plan was scored from the high to the highest level, and the overall assessment results of all lesson plans was at the high level $(\overline{\mathrm{x}}=4.25$, $\mathrm{SD}=0.60$ ).

Part 2 the effectiveness of the Flipped Classroom lesson plans for Primary 5 students comparing with the 75/75 criteria. The researcher examined the effectiveness of the lesson plans calculated from the scores of assessment of students' learning behaviours in class, assessment of worksheets, and pretest and posttest scores. The results were presented in the following table.

Table 2. The effectiveness of the Flipped Classroom lesson plans for Primary 5 students.

\begin{tabular}{|c|c|c|c|}
\hline Activities/Scores & Full score & $\begin{array}{c}\text { Average } \\
\text { score }\end{array}$ & Percentage \\
\hline Activity 1 & 10 & 8.09 & 80.90 \\
\hline Activity 2 & 10 & 8.44 & 84.40 \\
\hline Activity 3 & 10 & 7.88 & 78.80 \\
\hline Activity 4 & 10 & 8.50 & 85.00 \\
\hline Activity 5 & 10 & 8.41 & 84.10 \\
\hline
\end{tabular}


UMGCINMATIC : $1^{\text {st }}$ Rethinking Education during Covid-19 Era: Challange and Innovation Volume 1 No 2

\begin{tabular}{|c|c|c|c|}
\hline Activities/Scores & Full score & $\begin{array}{c}\text { Average } \\
\text { score }\end{array}$ & Percentage \\
\hline Activity 6 & 10 & 8.19 & 81.90 \\
\hline Activity 7 & 10 & 8.41 & 84.10 \\
\hline Activity 8 & 10 & 8.22 & 82.20 \\
\hline Activity 9 & 10 & 8.44 & 84.40 \\
\hline Activity 10 & 10 & 8.47 & 84.70 \\
\hline \multicolumn{2}{|c|}{ Average score } & 8.30 & \\
\hline \multicolumn{3}{|c|}{ E1 } & 83.03 \\
\hline After learning & 30 & 23.56 & 78.54 \\
\hline \multicolumn{3}{|c|}{ E2 } & 78.54 \\
\hline
\end{tabular}

Table 2 the evaluation results showed the efficiency processes of the Flipped lesson plans for Primary 5 students was (E1) of 83.03 and the effectiveness of the lesson plans (E2) was 78.54. Consequently, the efficiency of the lesson plans development (E1/E2) was 83.03/78.54 which is higher than the preset criteria of 75/75.

Table 3. Effectiveness Index of Flipped Classroom lesson plans for Primary 5 Students $(\mathrm{N}=32)$

\begin{tabular}{|c|c|c|}
\hline Total score of pretest (30) & Total score of posttest (30) & Effectiveness Index (E.I.) \\
\hline 328 & 754 & 0.6741 \\
\hline
\end{tabular}

From Table 3, it was found that the effectiveness index of the flipped classroom lesson plans for Primary 5 students $(\mathrm{N}=32)$, as overall, was averagely 0.6741 . It is indicated that the Flipped Classroom lesson plans designed by the researcher increased the student achievement by $67.41 \%$.

Part 3 The study results of the learning achievement of Primary 5 students who studied by using flipped classroom lesson plans in the situation of COVID-19.

3.1 The Growth scores of students' English learning achievement

The growth score of English language achievement of Primary 5 students analysed by using relative ability growth scores according to the formula of Sirichai Kanchanawasi (2009), the criteria for assessment of the ability growth scores was as follows:

$\begin{array}{cl}\text { Growth score (percentage) } & \text { Meaning } \\ 76-100 & \text { Very high development } \\ 51-75 & \text { High development } \\ 26-50 & \text { Fair development } \\ 1-25 & \text { Less development } \\ \text { Lower than } 0 & \text { No development }\end{array}$


The results of the analysis the development of English language learning achievement of Primary 5 students was shown in the following table.

Table 4. The results of the analysis of the development of Primary 5 students who studied by using the flipped classroom lesson plans in the situation of COVID-19.

\begin{tabular}{|c|c|c|c|c|}
\hline Student & $\begin{array}{c}\text { Before } \\
\text { learning }\end{array}$ & $\begin{array}{c}\text { After } \\
\text { learning }\end{array}$ & $\begin{array}{l}\text { Percentage of } \\
\text { development }\end{array}$ & $\begin{array}{c}\text { Level of } \\
\text { development }\end{array}$ \\
\hline 1 & 16 & 26 & 71.43 & high \\
\hline 2 & 4 & 18 & 53.85 & high \\
\hline 3 & 13 & 19 & 35.29 & fair \\
\hline 4 & 11 & 20 & 47.37 & fair \\
\hline 5 & 14 & 22 & 50.00 & fair \\
\hline 6 & 11 & 28 & 89.47 & Very high \\
\hline 7 & 12 & 24 & 66.67 & high \\
\hline 8 & 9 & 19 & 47.62 & fair \\
\hline 9 & 10 & 27 & 85.00 & Very high \\
\hline 10 & 13 & 23 & 58.82 & high \\
\hline 11 & 10 & 26 & 80.00 & Very high \\
\hline 12 & 8 & 27 & 86.36 & Very high \\
\hline 13 & 9 & 28 & 90.48 & Very high \\
\hline 14 & 14 & 26 & 75.00 & high \\
\hline 15 & 10 & 22 & 60.00 & high \\
\hline 16 & 16 & 25 & 64.29 & high \\
\hline 17 & 12 & 22 & 55.56 & high \\
\hline 18 & 8 & 20 & 54.55 & high \\
\hline 19 & 6 & 20 & 58.33 & high \\
\hline 20 & 10 & 24 & 70.00 & high \\
\hline 21 & 7 & 22 & 65.22 & high \\
\hline 22 & 9 & 24 & 71.43 & high \\
\hline 23 & 13 & 24 & 64.71 & high \\
\hline 24 & 10 & 25 & 75.00 & high \\
\hline 25 & 7 & 24 & 73.91 & high \\
\hline 26 & 14 & 27 & 81.25 & Very high \\
\hline 27 & 11 & 26 & 78.95 & Very high \\
\hline 28 & 10 & 24 & 70.00 & high \\
\hline 29 & 8 & 23 & 68.18 & high \\
\hline 30 & 8 & 23 & 68.18 & high \\
\hline 31 & 7 & 22 & 65.22 & high \\
\hline 32 & 8 & 24 & 72.73 & high \\
\hline Average & 10.25 & 23.56 & 67.34 & \\
\hline
\end{tabular}


UMGCINMATIC : $1^{\text {st }}$ Rethinking Education during Covid-19 Era: Challange and Innovation Volume 1 No 2

\begin{tabular}{|c|c|c|c|c|}
\hline Student & $\begin{array}{c}\text { Before } \\
\text { learning }\end{array}$ & $\begin{array}{c}\text { After } \\
\text { learning }\end{array}$ & $\begin{array}{c}\text { Percentage of } \\
\text { development }\end{array}$ & $\begin{array}{c}\text { Level of } \\
\text { development }\end{array}$ \\
\hline score & & & & high \\
\hline Percentage & $\mathbf{3 4 . 1 7}$ & $\mathbf{7 8 . 5 4}$ & & \\
\hline
\end{tabular}

Table 4 presented the relative growth scores of the academic achievement of Primary 5 students who studied by using a flipped classroom lesson plans in the situation of COVID-19. It was found that the percentage of scores before learning was 34.17, the percentage of score after learning by using the designed lesson plans was 78.54, and the percentage students' growth scores was 67.34. Consequently, the overall development level of the students was considered at the high level.

Table 5 Summary of the analysis results of the relative growth scores of the academic achievement of Primary 5 students who studied by using the flipped classroom lesson plans in the situation of COVID-19.

Table 5. Summary of the analysis results of the relative growth scores

\begin{tabular}{|c|c|c|c|c|c|}
\hline \multicolumn{4}{|c|}{ Number of students classified by the level of development } & \multirow{2}{*}{ Total } \\
\hline Very high & high & Fair & Low & $\begin{array}{c}\text { No } \\
\text { development }\end{array}$ & \\
\hline 7 & 21 & 4 & 0 & 0 & 32 \\
\hline
\end{tabular}

According to the growth score shown in Table 6 regarding the academic achievement of Primary 5 students who studied using a flipped classroom lesson plans in the COVID-19 situation, there were 7 students had a very high improvement, 21 students with high level of development, and 4 students with fair level of development.

\section{DISCUSSION}

1. The results of the study of the evaluation results of the flipped classroom lesson plans for Primary 5 students showed that the overall mean was 4.25 and the standard deviation was 0.60 which was at the high level $(\overline{\mathrm{x}}=4.25, \mathrm{SD}=0.60)$. The assessment of the Flipped Classroom lesson plans for Primary 5 students showed that efficiency of the lesson plans compared with the standard quality criteria $75 / 75$ (E1/E2) was 83.03/78.54, higher than the preset criteria. It is possible that because the researcher had studied about concept of the flipped classroom learning management and designed the learning activities based on the 6-stage process by applying the concept of the flipped classroom that focuses on enhancing the students' ability to construct the knowledge to be connected and integrated with the meaning of the body of knowledge for learners to understand. Moreover, the students had the opportunity to use analytical thinking to link the events with the prior knowledge in order to understand and create new knowledge, as well as, apply new knowledge to understand other problem situations in the form of expanding or applying knowledge. Especially, it is important that teachers need to monitor the progress of normal students that whether they understand well before begin the new lesson which consistent with Bergmann and Sams (2012). 


\section{UMGCINMATIC : $1^{\text {st }}$ Rethinking Education during Covid-19 Era: Challange and Innovation}

Volume 1 No 2

2. The results of the study of the effectiveness index of the Flipped Classroom lesson plans for Primary 5 students $(\mathrm{N}=32)$ revealed that the overall average effectiveness index was 0.6741 . This means that the Flipped Classroom lesson plans improved the students' learning achievement 67.41 percent higher.

3. The results of a study of the learning achievement of Primary 5 students who studied by using a flipped classroom lesson plans in the situation of COVID-19 by analyzing the relative growth scores of learning achievement revealed that the percentage of pretest scores was 34.17 , posttest score was 78.54, and the percentage of development was 67.34. It can be interpreted that the level of the development according to the criteria was high. Based on the criteria, there were 7 students with very high development, 21 students with high development, and 4 students with fair development. The results of this research may be due to learning management by applying the concept of flipped classroom to improve English language learning achievement and to improve English language learning achievement focuses on students to connect their basic knowledge with new knowledge and emphasizes on a relaxed atmosphere.

\section{CONCLUSION}

This helps students can absorb knowledge and directly experience with the development in all aspects including stimulating the attention of students to be enthusiastically alert and responsive at all times which can lead to the creation of knowledge and understanding from what lessons they have learnt. Applying knowledge, all aspects of the process, and emotions of learners to develop into new knowledge successfully, learning activities by implementing flipped classroom to enhance English learning achievement is believed that มี that teaching English requires skill training. Remembering many rules is difficult for students to understand, it is boring and takes a long time to remember as students have no time to practice. Many academicians have been searching for a solution to the problem by creating new ideas of teaching and learning. The current concept seems suitable for solving the problem and the current situation, the concept of "Teach less but Learn more", teaches less but learns a lot, is one of the ideas that supports and is a guideline to solve problems. Many educational institutions have applied this concept to use in the classroom at various educational levels in order to enable students to learn anywhere, anytime without limitation (Bamrung Ngamkarn, 2013).

\section{ACKNOWLEDGEMENTS}

To be successfully complete, this research was funded by the project of the Research Grant for New Scholars. I do appreciate and would like to extend deeply thanks to Loei Primary Educational Service Area Office 2. Thank you Dr.Wanida Simpol, the research advisor and Dr. Nanthana Sarakitjanont for giving me suggestions, ideas, as well as guiding me to get through obstacles and difficulties in conducting research.

\section{REFERENCES}

Ministry of Education. Basic Education Core Curriculum (2008). Bangkok: Agricultural Cooperative Association of Thailand Printing House, 2008.

Nattakarn Deewtrakul. (2017). The Use of the Classroom Model in Reverse in Language Teaching Management. English at the higher education level. Sripatum: University 
Tissana Khamanee (2005). Pedagogical Science. Bangkok : Chulalongkorn University.

Boonchom Srisaat. (2002). Preliminary research. Print the 7th time. Bangkok: Suree Wiyasan Announcement of O-Net Primary 6, almost all subjects, the average is less than half. (July 22, 2021). Retrieved from http://education.kapook.com.

Pornphimon Riyay and Thanangkoon Khamsri. (2012). Developing listening-speaking skills in English of the 1st-year student using a multimedia computer program. Chiang Mai: University

Rattana Buason. (2011). Research and Development of Educational Innovations. Second printing. Nakhon Sawan: Rimping Printing

Nong Hin Community School. Report of quality assessment within educational institutions. Loei: Copy document, 2021

Ladawan Kanthamala. (2017). Effects of the use of a reverse classroom teaching method that promotes knowledge creation and problem-solving skills Information Technology 5 of students in Mathayom 3. Ramkhamhaeng : University.

National Institute of Educational Testing. (2013). Analysis of O-NET Primary 6 exam scores, national level. Retrieved August 15, 2021. From www.niets.or.th/index.php/research_th/download/12.

Somnuk Phatthiyathanee Educational Measurement. 4th Edition. Kalasin: Coordinate Printing. (2003). Creation of research tools. Mahasarakham: Department of Educational Research and Development Faculty of Education, Mahasarakham University, 2003.

Sukrai Nantaburom. (2015). The relationship between integrated learning methods. Inverted classroom, learning area, and in-depth learning. Bangkok: Chulalongkorn University

Sommai Kaewkanha. (2015). Development of inverted classroom cooperative learning activities using ED media, LTV. Mahasarakham Rajabhat: Mahasarakham.

Surachai Chokkanchit Thai. “Coronavirus Outbreak 2019 (COVID 19)” (17 September 2021). Retrieved from https://he01.tci-thaijo.org/index.php/JPMAT/article/view/242185/164693.

Sumitra Angwattanakul. (1996). Methods of teaching English. Bangkok: Chulalongkorn University. Sudchalerm Sastrapruek, and Paisan Poksuwan. (2015). Good Governance for Management and Development of Community Enterprises. Community Development Journal and quality of life, 3(3), 271-283.

Sirikorn Bamrungkit, Santi Wichakkanalan, and Thoothong Kwangsawas. (2019). Teaching style English with blended learning to promote communication skills. Research Journal Khon Kaen University (Graduate edition) in the field of humanities and social sciences. 7(2), 59- 70.

Sirichai Kanchanawasee. (2009). The traditional theory of testing. 6th edition, Bangkok: Chulalongkorn University.

Lee, G. \& Wallace, A. (2018). Flipped Learning in English as a Foreign Language Classroom: Outcomes and Perceptions. TESOL Quarterly. 52(1), 62-84.

Thu May, N., \& Minh H, T. (2020). Information Technology Freshmen' Attitudes towards English Language Learning with Blended Learning Course at FPT Polytechnic College. International Journal of Scientific and Research Publication 10(8), 665-670.

Vijaya Kumar, S., \& Viswanathan, R. (2018). Performance Analysis in Blended and Online Classrooms: An Experimental Study. CALL-EJ.19(2), 100-124.

Olivares, J. (2020). The Enhancement of English-Speaking Ability of the Visually Impaired Students Using Blended Learning. Rajabhat University. Udon Thani. 8(1), 56-62. 